\title{
Peningkatan Kemampuan Pemahaman Konsep Matematika Melalui Pendekatan Matematika Realistik Berbantuan Youtube
}

\section{Khairunnisa Siregar ${ }^{1}$, Sri Muliatik ${ }^{2}$, Yenni Novita Harahap ${ }^{3}$}

\author{
1,2,3 Universitas Alwashliah Medan, Medan, Indonesia
}

\section{ART I CLE I N F O}

\section{Article history:}

Received September 11, 2021

Revised September 12, 2021

Accepted October 14, 2021

Available online October 25, 2021

Kata Kunci:

Pemahaman Konsep, Pendekatan Matematika Realistik, Youtube

Keywords:

Concept Understanding, Realistic Mathematical Approach, Youtube

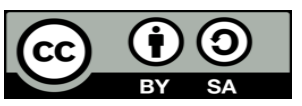

This is an open access article under the CC BY-SA license.

Copyright (C) 2021 by Author. Published by Universitas Pendidikan Ganesha.

\begin{abstract}
A B S T R A K
Kegiatan pembelajaran matematika lebih banyak dilakukan dengan menanamankan konsep-konsep matematis kepada siswa, hanya saja pada pelaksanaannya tidak semua siswa mampu memahami konsep dengan baik. Tujuan dari penelitian ini yakni untuk memberikan variasi pembelajaran yang tepat dan efektif dalam kemapuan pemahaman konsep matematika pada meteri lingkaran. Penelitian ini merupakan jenis penelitian ekperimen semu (quasi ekperimen) dengan jumlah populasi yakni seluruh siswa kelas VII SMP. Penarikan sampel dilakukan dengan teknik random sampling, dengan jumlah sampel akhir yakni sebanyak 60 siswa. Pengumpulan data dalam penelitian dilakukan dengan teknik wawancara, observasi, dokumentasi, dan tes, dengan instrument penelitian berupa Bentuk instrumen tes berisi materi perkalian bilangan bulat. Data hasil penelitian kemudian dianalisis dengan menentukan atau menghitung skor mentah tiap-tiap anggota sampel yang dipilih secara acak, baik pada kelas eksperimen maupun kelas kontrol. Setelah itu dilakukan penghitungan rata-rata (mean) dan standar deviasi baik hasil tes siswa yang diajarkan dengan model pembelajaran matematika realistik berbantuan youtube maupun hasil tes siswa yang diajarkan dengan metode konvensional. Hasil analisis penelitian menunjukkan bahwa terjadi peningkatan kemampuan pemahaman konsep matematika rata-rata sebesar $0,8 \%$ dan dapat dikatagorikan tinggi menutur tabel skor N-Gain. Sehingga Ho ditolak dan Ha diterima dalam penelitian ini yaitu terdapat peningkatan kemampuan pemahaman konsep matematika siswa melalui pendekan matematika realistik berbantuan youtube.
\end{abstract}

\begin{abstract}
A B S T RACT
Mathematics learning activities are done mainly by instilling mathematical concepts in students. It is just that in practice, not all students can understand concepts well. This study aims to provide appropriate and effective variations of learning in the ability to understand mathematical concepts in circle material. This research is a type of quasi-experimental research (quasi-experimental) with a total population of all seventh-grade students of SMP. Sampling was done by random sampling technique, with a final sample of 60 students. Data collection in the study was carried out by interview, observation, documentation, and test techniques, with the research instrument in the form of a test instrument containing material for the multiplication of integers. The research data were then analyzed by determining or calculating the raw score of each sample member selected at random, both in the experimental and control classes. After that, the average (mean) and standard deviation were calculated for the test results of students taught with realistic mathematics learning models assisted by youtube and the results of students' tests taught by conventional methods. The analysis results showed an increase in the ability to understand mathematical concepts by an average of $0.8 \%$ and could be categorized as high according to the N-Gain score table. So Ho is rejected, and Ha is accepted in this study. Namely, there is an increase in students' understanding of mathematical concepts through a realistic mathematical approach assisted by YouTube.
\end{abstract}

\section{PENDAHULUAN}

Pelajaran matematika merupakan salah satu mata pelajaran wajib yang harus dibelajarkan pada pendidikan formal di Indonesia. Dalam pelajaran matematika proses pembelajaran eksternal dapat dilihat melalui interaksi antara siswa, perangkat pembelajaran dan guru (Laknasa et al., 2021; Salim \& Maryanti, 2017; Sulistyo \& Alyani, 2021). Melalui kegiatan pembelajaran matematika siswa dilatih untuk dapat memecahkan berbagai macam permasalahan yang ada dalam kehidupan sehari-hari (Rostika \& Junita, 2017). Pembelajaran matematika memungkinkan siswa untuk mengembangkan kemampuan berpikir logis, analitis, sistematis, kritis logis, kreatif, dan bekerjasama, melalui proses-proses penanaman konsep 
matematis (Haryanti \& Sari, 2019). Untuk memaksimalkan proses pembelajaran matematika maka proses pembelajaran matematika lebih ditekankan pada peningkatan kemampuan pemahaman konsep (Leonindita et al., 2020). Kemampuan pemahaman konsep merupakan unsur penting dalam belajar matematika. Penugasan terhadap banyak konsep, memungkinkan seorang dapat memecahkan masalah dengan lebih baik, sebab untuk memecahkan masalah diperlukan aturan-aturan yang didasarkan pada konsep-konsep yang dimiliki (Amam, 2017; Hidayat \& Sariningsih, 2018; Suraji \& Saragih, 2018). Pada dasarnya konsep diartikan sebagai ide abstrak yang memungkinkan seseorang untuk dapat mengelompokkan objek atau kejadian yang menerangkan apakah objek atau kejadian itu merupakan contoh atau bukan contoh dari sebuah ide (Fajar et al., 2019). Kemampuan pemahaman konsep dan pemecahan masalah matematis merupakan dua kemampuan yang telah dinyatakan berdasarkan standar isi (SI) mata pelajaran matematika untuk satuan pendidikan, yang didalamnya dijelaskan bahwa tujuan pembelajaran matematika di sekolah agar siswa memiliki kemampuan untuk Memahami konsep matematika, menjelaskan keterkaitan antar konsep dan mengaplikasikan konsep atau algoritma secara luwes, akurat, efesien dan tepat dalam pemecahan masalah, Menggunakan penalaran pada pola dan sifat, melakukan manipulasi matematika dalam membuat generalisasi, serta menyusun bukti atau menjelaskan gagasan dan pernyataan matematika (Gunawan \& Putra, 2019; Lestari et al., 2019; Raharjo \& Sulaiman, 2017).

Siswa yang telah paham terhadap sesuatu, akan dapat mengungkapkan kembali konsep yang dipelajarinya dengan dengan menggunakan bahasanya sendiri baik itu suatu konsep itu sendiri, objekobjek yang membentuk konsep tersebut, contoh dari konsep tersebut, bentuk representasi matematikanya, prosedurnya, maupun kaitan konsep matematika tersebut dengan konsep lainnya (Oktoviani et al., 2019). Hanya saja kenyataan dilapangan ditemukan siswa masih kurang memahami konsep matematika dengan baik (Selvianiresa, 2017; Yanti et al., 2019). Kurangnya tingkat pemahaman konsep ini cenderung disebabkan karena guru belum menerapkan variasi dalam metode dan media pembelajaran sehingga kemampuan pemahaman terhadap konsep-konsep tergolong rendah (Sari, 2019). Rendahnya tingkat pemahaman konsep serta kurangnya inovasi guru dalam kegiatan belajar mengajar tentunya akan berdampak pada penuruhan hasil belajar dan kemampuan matematis siswa. Oleh karena itu, dibutuhkan suatu pendekatan pembelajaran matematika yang dekat dengan pikiran siswa atau selalu mengaitkan matematika dalam kehidupan sehari-hari. Salah satu pendekatan yang dapat digunakan yakni pendekatan pembelajaran Matematika Realistik (PMR). Pembelajaran Matematika Realistik (PMR) merupakan pendekatan yang bermula pada permasalahan yang nyata bagi siswa, mengutamakan keterampilan proses (process of doing mathematics), diskusi dan kolaborasi, interaktif (tutor sebaya) dengan maksud agar mereka berkekuatan penuh untuk bereksperimen baik secara individu maupun kelompok (Jeheman et al., 2019; Rismawati \& Komala, 2018; Siregar et al., 2020; Yandiana \& Ariani, 2020). Pendekatan PMR memiliki prinsip aktivitas (doing), konstrutivis, realitas (kebermaknaan proses aplikasi), pemahaman (menemukan informasi dalam konteks melalui refelksi, informal ke formal), inter-twinment (keterkaitan interkoneksi antar konsep), interaksi (pembelajaran sebagai aktivitas sosial), dan bimbingan (membimbing siswa untuk menemukan suatu konsep matematika) (Warsito \& Nuraini, 2019; Yulianty, 2019).

Kegiatan pembelajaran menggunakan pendekatan PMR lebih ditekankan pada pengaitan materi ajar dengan kehidupan kehidupan nyata dan menjadikan pengalaman peserta didik sebagai titik awal pembelajaran (Herzamzam, 2018). Sehingga melalui proses pembelajaran yang demikian siswa akan dibentuk untuk memiliki pola pikir yang praktis, logis, kritis, dan jujur dengan berorientasi pada penalaran matematika dalam menyelesaikan masalah (Susanti, 2017). Tujuan dari pendekatan PMR yakni memberikan kesempatan kepada siswa untuk menemukan kembali dan merekonstruksi konsep-konsep matematika dengan mengaitkan konsep-konsep matematika dengan dunia nyata, sehingga siswa mempunyai pengertian yang kuat tentang konsep-konsep matematika (Jusmanidar, 2017). PMR akan secara operasional memberikan pengertian tentang relevansi serta kegunaan matematika (materi yang diajarkan) dengan dan atau dalam kehidupan sehari-hari (Purna \& Ardana, 2021). Semua kajian tersebut akan secara independen dikonstruksi dan dikembangkan oleh siswa. Selain itu, penyelesaian masalah tidak harus tunggal dan tidak harus sama antara satu siswa dengan siswa lainnya. Pemahaman konsep dengan PMR akan lebih sempurna jika disajikan mengunakan media pembelajaran. Tingginya perkembangan IPTEK pada bidang pendidikan, memungkinkan adanya penggunaan media berbasis teknologi. Salah satu media yang dapat digunakan yakni media video pembelajaran. Video merupakan suatu media untuk menunjukan sebuah unsur auditif (pendengaran) dan visual (penglihatan) yang bisa dihat ataupun kita dengarkan suaranya (Ismawati \& Mustika, 2021; Manshur \& Ramdlani, 2020). Video dapat diakses dengan cepat dan luas jika menggunakan internet. Sejauh ini kita mengetahui banyak sekali situs untuk berbagi video dan dapat kita manfaatkan untuk fasilitas mengembangkan sebuah channel 
pembelajaran berupa video yaitu YouTube. Dengan memanfaatkan Youtube sebagai media pembelajaran, maka siswa setiap saat dapat belajar dan mengulangi pembelajaran tersebut (Nugroho et al., 2019).

Beberapa penelitian yang telah dilakukan sebelumnya menyebutkan bahwa pendekatan PMR dapat digunakan untuk meningkatkan minat serta motivasi belajar matematika siswa kelas V SD (Herzamzam, 2018). Penelitian selanjutnya juga menyebutkan bahwa serangkaian kegiatan pembelajaran dengan PMR dapat membawa siswa dari situasi konkret menuju situasi yang lebih formal, sehingga siswa mampu mengerjakan bilangan pecahan dari bentuk kontektual dengan disertai alasan (Warsito \& Nuraini, 2019). Hasil penelitian lainnya juga menunjukkan bahwa terdapat pengaruh Pendekatan Pendidikan Matematika Realistik terhadap hasil belajar penjumlahan dan pengurangan pecahan di kelas V SD (Yandiana \& Ariani, 2020). Berdasarkan hasil beberapa penelitian tersebut dapat dikatakan bahwa pendekatan PMR, secara signifikan mampu membantu siswa untuk meningkatkan kemampuan matematis siswa, sehingga berdampak pada peningkatan hasil belajar. Hanya saja pada penelitian sebelumnya belum terdapat penelitian yang mengkaji penggunaan pendekatan PMR berbantuan media youtobe untuk meningkatkan pemahaman konsep siswa, sehingga pada penelitian ini difokuskan pada peningkatan kemampuan pemahaman konsep matematika melalui pendekatan matematika realistik berbantu youtube dengan tujuan untuk memberikan variasi pembelajaran yang tepat dan efektif dalam kemapuan pemahaman konsep matematika pada meteri lingkaran.

\section{METODE}

Penelitian ini merupakan jenis penelitian eksperimen semu (quasi eksperimen) yang dilakukan dengan tujuan untuk melihat akibat dari suatu perlakuan. Pada penelitian ini terdapat 2 variabel bebas dan 1 varibel terikat. Variabel bebasnya yakni pembelajaran matematika realistik berbantu youtube $\left(\mathrm{X}_{1}\right)$ dan pembelajaran konvensional $\left(\mathrm{X}_{2}\right)$. Sedangkan varibel terikatnya adalah kemampuan pemahamaham konsep matematika (Y). Populasi dalam penelitian ini yakni seluruh siswa kelas VII SMP Al Washliyah 8 Medan. Penarikan sampel penelitian dilakukan dengan menggunakan teknik random sampling, dan didapatkan hasil bahwa yang menjadi sampel penelitian yakni siswa kelas VII-1 dan VII-3 dengan jumlah siswa masing-masing 30 orang, sehingga jumlah sampel seluruhnya yakni sebanyak 60 siswa. Pengumpulan data dalam penelitian dilakukan dengan teknik wawancara, observasi, dokumentasi, dan tes. Teknik wawancara dilakukan untuk mengetahui dan menilai keadaan siswa, misalnya mencari data latar belakang siswa dan kesulitan belajar siswa. Sedangkan teknik observasi dilakukan dengan melakukan pengamatan secara langsung mengenai proses pembelajaran di kelas dan digunakan untuk mendapatkan data, tingkah laku siswa pada saat mengikuti pembelajaran serta observasi juga dilakukan dengan melakukan wawancara serta mengamati proses pembelajaran. Selanjutnya, teknik dokumentasi digunakan untuk mendapatkan daftar nama siswa kelas VII SMP Al Washliyah 8 Medan yang menjadi populasi, hasil belajar, bukti foto selama kegiatan pembelajaran di VII SMP Al Washliyah 8 Medan dan data-data yang diperlukan dalam penelitian. Teknik tes dalam penelitian dilakukan dengan instrument tes tulis. Bentuk instrumen tes berisi materi perkalian bilangan bulat. Tes ini berfungsi untuk mengukur kemampuan awal siswa dalam materi lingkaran (pretest) dan kemampuan akhir dalam materi lingkaran (posttest).

Analisis data dalam penelitian dilakukan dengan menentukan atau menghitung skor mentah tiap-tiap anggota sampel yang dipilih secara acak, baik pada kelas eksperimen maupun kelas kontrol. Setelah itu dilakukan penghitungan rata-rata (mean) dan standar deviasi baik hasil tes siswa yang diajarkan dengan model pembelajaran matematika realistik berbantu youtube maupun hasil tes siswa yang diajarkan dengan metode konvensional. Analisis kemudian dilanjutkan pada pengujian hipotesis yang dilakukan dengan cara membandingkan harga $t_{\text {hitung dengan }} t_{\text {tabel }}$ pada $\mathrm{N}=58$ dengan tingkat kepercayaan $\alpha=0,05$ dengan ketentuan jika $t_{\text {hitung }}>t_{\text {tabel }}$ maka $H_{o}$ ditolak $H_{a}$ diterima dengan pengertian ada pengaruh model pembelajaran matematika realistik berbantuan youtube terhadap kemampuan pemahaman konsep matematika pada materi perkalian bilangan bulat.

\section{HASIL DAN PEMBAHASAN}

Hasil

Penelitian ini dilaksanakan di sekolah SMP Alwashliyah 8 Medan, pada materi perkalian bilangan bulat, peserta didi kelas VIII dibagi menjadi dua kelas yaitu kelas yang diberikan perlakuan Pendekatan Matematika Realistik Berbantu Youtube dabn kelas yang diberikan perlakuan pembelajaran konvensional. Penelitian dilaksanakan untuk mengetahui kemampuan pemahaman konsep pada materi perkalian bilangan bulat, peserta yang diberikan perlakuan PMR berbantu Youtube mampu memberikan hasil yang 
berbeda dengan kelas yang hanya diberikan pembelajaran konvensional. Penelitian ini memberi kesempatan kepadda peserta didik terlibat langsung dalam pembelajaran, sehingga indikator pemebelajaran tercapai dengan baik dan tepat. Penelitian diawali dengan melaksanakan pretest, dengan tujuan untuk mengetahui kemampuan awal peserta didik, yang bertujuan untuk mengetahui kelas yang akan dijadikan kelas eksperimen (PMR berbantu Youtube) dan kelas kontrol (pembelajaran Konvensional), sehingga memudahkan peneliti mengaplikasikan perlakuan sesuai kebutuhan peserta didik. Untuk melihat hasil tes kemapuan awal dalam kemampuan pamahaman konsep kelas VII-1 dan VII3 dibagi menjadi dua kelompok yatu tinggi dan rendah. Nilai yang menjadi patokan untuk menentukan tinggi atau rendah adalah nilai yang digunakan sebagai kriteria ketuntasan minimal (KKM). Nilai KKM yang digunakan pada sekolah tersebut adalah nilai KKM tunggal yaitu 72. Sehingga dapat disimpulkan bila nilai pretest < KKM dikatakan rendah dan nilai pretest > KKM dikatakan tinggi.

Hasil yang diperoleh dari penyelesaian soal pretest kelas VII-1 menunjukan 14 (46,7\%) peserta didik berada dikatagori tinggi dan 16 (53,3\%) berada dikatagori rendah. Sedangkan, kelas VII-2 memperoleh 12 (40\%) peserta didik berada dikatagori tinggi dan 18 (60\%) peserta didik dikatagori rendah. Dengan demikian dapat disimpulkan bahwa kelas VII-2 lebih baik dibandingkan dengan VII-1. Hasil analisis nilai kemampuan pemahaman konsep kelas VII-1 diketahui nilai minimun (terendah) adalah 25.00, nilai maximum (tertinggi) sebesar 75.00 dengan rata-rata (mean) sebesar 54.35. Sedangkan untuk kemampuan pemahaman konsep kelas VII-3 diketahui nilai minimun (terendah) adalah 22.22, nilai maximum (tertinggi) sebesar 72.22 dengan rata-rata (mean) sebesar 53.15. Dari tabel di atas dapat disimpulkan bahwa kelas yang akan diberikan perlakuan PMR berbantu youtube (kelas eksperimen) adalah kelas VII-3 dan kelas yang diberikan pendekatan konvesional (kelas kontrol) adalah kelas VII-1.

Setelah dilakukan uji hasil pretest analisis dilanjutkan pada pengujian normalitas yang dilakukan untuk menilai sebaran data pada sebuah kelompok data atau variabel penelitian. Pengujian normalitas dalam penelitian dilakukan dengan menggunakan uji lilliefors, hasil analisis menunjukkan data kemampuan pemahaman konsep matematika dinyatakan berdistribusi normal dan dapat dibuktikan dengan hasil L hitung $<$ Ltabel artinya $0,113494<0,161$. Sehingga dapat disimpulkan bahwa data yang telah dikumpulkan berdistribusi normal atau diambil dari populasi normal. Analisis kemudian dilanjutkan pada uji homogenitas yang dilakukan melalui F-Test Two-Sampel for Varians dengan syarat $F_{\text {hitung }}<\mathrm{F}_{\text {tabel. }}$. Hasil uji homogenitas hasil analisis menunjukkan bahwa data bersifat homogen, hal ini dapat dilihat dari nilai $F_{\text {hitung }}<\mathrm{F}_{\text {tabel }}$ atau 1,154686 $<1,860811$. Pengujian hipotesis dilakukan untuk menegaskan hiporesis yang telah dipaparkan, pengujian telah dilakukan dengan menganalisis setiap hasil yang diperoleh secara manual dan dengan menggunakan t-Test: Two-Sample Assuming Equal Variances pada excel. Hasil pengujian hipotesis diperoleh bahwa nilai value $>0,05$ yang artinya 2,3963 $>0,05$ atau dapat diketahui dengan membandingkan Ttabel dengan Thitung. Ttabel $(0,05)$ adalah 2,00172 dan nilai Thitung adalah 6,38466 dapat dikatakan Thitung > Ttabel yang artinya 6,38466 > 2,00172. Dapat disimpulkan bahwa Ho ditolak sehingga Ha diterima dalam penelitian ini yaitu terdapat peningkatan kemampuan pemahaman konsep matematika siswa melalui pendekan matematika realistik berbantu youtube. Pembelajaraan mengakibatkan terjadinya peningkatan kemampuan pemahaman konsep. Hasil analisis N-gain diperoleh bahwa kelompok control 0,4 dengan katagori sedang dan kelompok eksperiment 0,8 dengan katagori tinggi.

\section{Pembahasan}

Adanya peningkatan kemampuan pemahaman konsep matematika siswa pada penelitian ini tidak terlepas dari penggunaan pendekatan matematika realistik (PMR) berbatuan media youtobe. Pendekatan matematika realistik pada dasarnya merupakan suatu pendekatan pembelajaran yang dimulai dari sesuatu yang real sehingga siswa dapat terlibat dalam proses pembelajaran secara bermakna (Afsari et al., 2021; Uskono et al., 2020). PMR bertitik tolak pada realita atau konteks nyata yang berada di sekitar siswa untuk mengawali kegiatan pembelajaran dan akhirnya digunakan untuk menyelesaikan masalah dalam kehidupan sehari-hari (Rismawati \& Komala, 2018). Ide utama dari PMR adalah bahwa siswa harus diberi kesempatan untuk menemukan kembali (reinvent) ide dan konsep matematika dengan bimbingan orang dewasa melalui penjelajahan berbagai situasi dan persoalan-persoalan dunia nyata atau real world (Lapase, 2020). Pendidikan matematika realistik memiliki tiga karakeristik, yaitu guided reinvention (menemukan kembali), didactical phenomenology (phenomena didaktik), self develoved model (pengembangan model sendiri) (Agusta, 2020; Wati \& Kurniasih, 2021). Adapun langkah-langkah pembelajaran metematika dengan pembelajaran matematika realistik adalah memahami masalah kontekstual, menyelesaikan masalah konstekstual, membagikan dan mendiskusikan jawaban, menarik kesimpulan (Rahayu et al., 2019). Seperti yang telah disampaikan sebelumnya bahwa pembelajaran dengan menggunakan pendekatan matematika reaslistik (PMR) akan lebih maksimal jika disertai dengan pengguan media pembelajaran, hal ini dikarenaka media pembelajaran dapat digunakan sebagai jembatan 
penghubung penyampaian materi antara guru dan siswa (Artika et al., 2019). Media pembelajaran dapat dimanfaatkan untuk membantu siswa memahami suatu objek/ kejadian tertentu, memanipulasi keadaan/peristiwa tertentu, menambah gairah serta motivasi belajar siswa (Manshur \& Ramdlani, 2020). Pada abad ke-21 youtube merupakan media lebih praktis dalam mencari pengetahuan karena Youtube segala informasi mudah didapatkan dan dinikmati semua kalangan (Suwarno, 2017). Youtobe menjadi media sharing video online terbesar dan paling populer di dunia internet, maka menjadikan youtube sebagai media pembelajaran merupakan suatu pemanfaatan yang baik (Nugroho et al., 2019).

Penggunaan pendekatan pembelajaran matematika realistik berbatuan media youtobe sangatlah dibutuhkan dalam proses pembelajaran matematika, hal ini dikarenakan dalam pembelajaran matematika siswa lebih ditekankan pada penanaman-penanaman konsep matematis. Hasil yang diperoleh pada penelitian ini sejalan dengan hasil penelitian terdahulu yang juga menyebutkan bahwa pendekatan PMR dapat digunakan untuk meningkatkan minat serta motivasi belajar matematika siswa kelas V SD (Herzamzam, 2018). Penelitian selanjutnya juga menyebutkan bahwa serangkaian kegiatan pembelajaran dengan PMR dapat membawa siswa dari situasi konkret menuju situasi yang lebih formal, sehingga siswa mampu mengerjakan bilangan pecahan dari bentuk kontektual dengan disertai alasan (Warsito \& Nuraini, 2019). Hasil penelitian lainnya juga menunjukkan bahwa terdapat pengaruh Pendekatan Pendidikan Matematika Realistik terhadap hasil belajar penjumlahan dan pengurangan pecahan di kelas V SD (Yandiana \& Ariani, 2020). Berdasarkan hasil penelitian yang didukung oleh hasil penelitian terdahulu, dapat dikatakan bahwa pendekatan matematika relaistik berbantuan media youtobe sangat cocok dibelajarkan pada siswa karena mampu meningkatkan pemahaman konsep matematika, meningkatkan motivasi belajar, aktifitas belajar, serta mampu meningkatkan hasil belajar siswa.

\section{SIMPULAN}

Kemampuan pemahaman konsep matematika siswa mengalami peningkatan setelah dibelajarkan dengan pendekan matematika realistik berbantuan youtube. Sehingga berdasarkan hal tersebut dapat disimpulkan bahwa pendekan matematika realistik berbantuan youtube sangat cocok digunakan untuk meningkatkan kemampuan pemahaman konsep matematika siswa. Rekomendasi dengan menggunkan pembelajaran matematika realistik berbantu youtube dapat menjadi solusi untuk meningkatkan kemampuan pemahaman konsep matematika siswa.

\section{DAFTAR PUSTAKA}

Afsari, S., Safitri, I., Harahap, S. K., \& Munthe, L. S. (2021). Systematic Literature Review: Efektivitas Pendekatan Pendidikan Matematika Realistik Pada Pembelajaran Matematika. Indonesian Journal of Intellectual Publication, 1(3), 189-197. https://doi.org/10.51577/ijipublication.v1i3.117.

Agusta, E. S. (2020). Peningkatan Kemampuan Matematis Siswa Melalui Pendekatan Pendidikan Matematika Realistik. ALGORITMA: Journal of Mathematics Education, 2(2), 145-165. https://doi.org/10.15408/ajme.v2i2.17819.

Amam, A. (2017). Penilaian Kemampuan Pemecahan Masalah Matematis Siswa SMP. TEOREMA. https://doi.org/10.25157/.v2i1.765.

Artika, Vira, R., Sudrajat, R., \& Wijayanti, A. (2019). Pengaruh Model Realistic Mathematics Education (RME) Berbantu Media Kertas Lipat Terhadap Penanaman Konsep Bangun Datar. Jurnal Ilmiah Sekolah Dasar, 3(4), 481. https://doi.org/10.23887/jisd.v3i4.21784.

Fajar, A. P., Kodirun, K., Suhar, S., \& Arapu, L. (2019). Analisis Kemampuan Pemahaman Konsep Matematis Siswa Kelas VIII SMP Negeri 17 Kendari. Jurnal Pendidikan Matematika, 9(2), 229. https://doi.org/10.36709/jpm.v9i2.5872.

Gunawan, R. G., \& Putra, A. (2019). Pengaruh Strategi Belajar Aktif Sortir Kartu Terhadap Kemampuan Pemecahan Masalah Matematis. Jurnal Cendekia : Jurnal Pendidikan Matematika, 3(2), 362-370. https://doi.org/10.31004/cendekia.v3i2.119.

Haryanti, S., \& Sari, A. (2019). Pengaruh Penerapan Model Problem Based Instruction terhadap Kemampuan Pemecahan Masalah Matematis ditinjau dari Adversity Quotient Siswa Madrasah Tsanawiyah. JURING Journal for Research in Mathematics Learning), 2(1), 077. https: //doi.org/10.24014/juring.v2i1.6712.

Herzamzam, D. A. (2018). Peningkatkan Minat Belajar Matematika Melalui Pendekatan Matematika Realistik (Pmr) Pada Siswa Sekolah Dasar. Visipena Journal, 9(1), 67-80. https://doi.org/10.46244/visipena.v9i1.430. 
Hidayat, W., \& Sariningsih, R. (2018). Kemampuan Pemecahan Masalah Matematis dan Adversity Quotient Siswa SMP Melalui Pembelajaran Open Ended. JNPM (Jurnal Nasional Pendidikan Matematika), 2(1), 109. https://doi.org/10.33603/jnpm.v2i1.1027.

Ismawati, S., \& Mustika, D. (2021). Validitas Media Video Berbasis Animasi Dalam Pembelajaran Tematik. $\begin{array}{lllll}\text { Journal of Islamic } & \text { Education, } & 4(2), & 163-174 .\end{array}$ https://doi.org/https://doi.org/10.24256/iqro.v4i2.2251.

Jeheman, Akuila, A., Gunur, B., \& Jelatu, S. (2019). Pengaruh Pendekatan Matematika Realistik terhadap Pemahaman Konsep Matematika Siswa. Mosharafa: Jurnal Pendidikan Matematika, 8(2), 191-202. https://doi.org/10.31980/mosharafa.v8i2.454.

Jusmanidar, J. (2017). Meningkatkan Hasil Belajar Siswa pada Operasi Hitung melalui Pendekatan Matematika Realistik. JPPI (Jurnal Penelitian Pendidikan Indonesia), 3(1), 12. https://doi.org/10.29210/02017104.

Laknasa, D. P. A., Abdullah, A. W., Pauweni, K. A. Y., Usman, K., \& Kaluku, A. (2021). Meningkatkan Hasil Belajar Matematika Siswa Melalui Pembelajaran Multimedia Interaktif dengan Model Discovery Learning. Jurnal ilmiah matematika, sains dan teknologi, 9(2). https: //doi.org/10.34312/euler.v9i2.11100.

Lapase, M. H. (2020). Meningkatkan Hasil Belajar Matematika Materi Operasi Hitung Bilangan Bulat Melalui Metode Pembelajaran Kooperatif Tipe Jigsaw Siswa Kelas V SDN Penedapa Kecamatan Poso Pesisir Kabupaten Poso Propensi Sulawesi Tengah. JISIP (Jurnal Ilmu Sosial Dan Pendidikan), 4(2). https://doi.org/10.36312/jisip.v4i2.1087.

Leonindita, S., Fitria, R., Fitriani, A., Muktafi, M. R., Aliyyunisa, N., \& Rahmawati, F. (2020). Analisis Problematika Pembelajaran Daring Siswa Kelas Viii Pada Materi Baris Dan Deret Ditinjau Dari Pemahaman Konsep. Dharmas Education Journal, 1(2), 135-142.

Lestari, K. S., Nurjanah, S., Zanthy, \& Sylviana, L. (2019). Analisis Kemampuan Pemahaman Dan Pemecahan Masalah Matematik Siswa Smp Pada Materi Persamaan Linear Satu Variabel. JPMI (Jurnal Pembelajaran Matematika Inovatif), 2(3), 107. https://doi.org/10.22460/jpmi.v2i3.p107118.

Manshur, U., \& Ramdlani, M. (2020). Media Audio Visual Dalam Pembelajaran Pai. Seminar Nasional Hasil Riset Dan Pengabdian Ke-III, 5(1), 1-8. https://doi.org/10.35891/amb.v5i1.1854.

Nugroho, Zaid, K. U., Widada, W., Zamzaili, \& Herawaty, D. (2019). Pemahaman Konsep Matematika melalui Media Youtube dengan Pendekatan Etnomatematika. Jurnal Pendidikan Matematika Raflesia, 04(01), 96-106. https://doi.org/https://doi.org/10.33449/jpmr.v4i1.8953.

Oktoviani, V., Widoyani, Laras, W., \& Ferdianto, F. (2019). Analisis kemampuan pemahaman matematis siswa SMP pada materi sistem persamaan linear dua variabel. Edumatica: Jurnal Pendidikan Matematika, 9(1), 39-46. https://doi.org/10.22437/edumatica.v9i1.6346.

Purna, I. N., \& Ardana, I. M. (2021). Pengaruh Pendidikan Matematika Realistik Terhadap Hasil Belajar Matematika Siswa dengan Pengendalian Kemampuan Numerik. Jurnal Imiah Pendidikan Dan Pembelajaran, 5(1), 160. https://doi.org/10.23887/jipp.v5i1.32447.

Raharjo, J. F., \& Sulaiman, H. (2017). Mengembangkan Kemampuan Pemahaman Konsep Matematika Diskrit Dan Pembentukan Karakter Konstruktivis Mahasiswa Melalui Pengembangan Bahan Ajar Berbantuan Aplikasi Education Edmodo Bermodelkan Progresif Pace (Project, Activity, Cooperative And Exercise). TEOREMA: Teori Dan Riset Matematika, 2(1), 47. https: //doi.org/10.25157/teorema.v2i1.569.

Rahayu, Setyawan, Ageng, A., \& Wahyuni, P. (2019). Pengembangan Perangkat Pembelajaran Matematika dengan Pendekatan Matematika Realistik Berbasis Kuliner Melayu Riau di Sekolah Dasar. Aksiomatik, 7(3), 18-24.

Rismawati, R., \& Komala, E. (2018). Penerapan Pendekatan Pendidikan Matematika Realistik Untuk Meningkatkan Kemampuan Pemecahan Masalah Matematis Siswa. IndoMath: Indonesia Mathematics Education, 1(2), 129. https://doi.org/10.30738/indomath.v1i2.2770.

Rostika, D., \& Junita, H. (2017). Peningkatan Kemampuan Pemecahan Masalah Siswa SD dalam Pembelajaran Matematika Dengan Model Diskursus Multy Representation (DMR). EduHumaniora / Jurnal Pendidikan Dasar Kampus Cibiru, 9(1), 35. https://doi.org/10.17509/eh.v9i1.6176.

Salim, S., \& Maryanti, E. (2017). Pengembangan perangkat pembelajaran matematika melalui teori pembelajaran sibernetik berbantuan software derive. Jurnal Riset Pendidikan Matematika, 4(2), 229. https://doi.org/10.21831/jrpm.v4i2.16068.

Sari, R. K. (2019). Analisis Problematika Pembelajaran Matematika Di Sekolah Menengah Pertama Dan Solusi Alternatifnya. Prismatika: Jurnal Pendidikan Dan Riset Matematika, 2(1), 23-32. https://doi.org/10.33503/prismatika.v2i1.510. 
Selvianiresa, D. (2017). Kesulitan Siswa Sekolah Dasar Pada Materi Nilai Tempat Mata Pelajaran Matematika di Kelas I SD. Pendas: Jurnal Ilmiah Pendidikan Dasar, 2(1), 65. https://doi.org/10.23969/jp.v2i1.451.

Siregar, S. U., Harahap, A., Milfayetti, S., \& Hajar, I. (2020). Peningkatan Kemampuan Komunikasi dan SelfEfficacy Matematis Siswa melalui Pendekatan Pembelajaran Matematika Realistik. Jurnal Penelitian Dan Pengkajian Ilmu Pendidikan: E-Saintika, 4(2), 151. https://doi.org/10.36312/esaintika.v4i2.207.

Sulistyo, R., \& Alyani, F. (2021). Analisis Kesulitan Peserta Didik dalam Pembelajaran Daring Matematika di Masa Pandemi COVID-19. Jurnal Cendekia: Jurnal Pendidikan Matematika, 5(3), 2460-2470. https://doi.org/10.31004/cendekia.v5i3.849.

Suraji, S., \& Saragih, S. (2018). Analisis Kemampuan Pemahaman Konsep Matematis dan Kemampuan Pemecahan Masalah Matematis Siswa SMP pada Materi Sistem Persamaan Linear Dua Variabel (SPLDV). Suska Journal of Mathematics Education, 4(1), 9. https://doi.org/10.24014/sjme.v4i1.5057.

Susanti, S. (2017). Meningkatkan Kemampuan Pemecahan Masalah Matematis dan Self-Efficacy Siswa MTs Melalui Pendekatan Pendidikan Matematika Realistik. Suska Journal of Mathematics Education, 3(2), 92. https: //doi.org/10.24014/sjme.v3i2.4148.

Suwarno, M. (2017). Potensi Youtube Sebagai Sumber Belajar Matematika. Pi: Mathematics Education Journal, 1(1), 1-7. https://doi.org/10.21067/pmej.v1i1.1989.

Uskono, I. V., Lakapu, M., Jagom, Y. O., Dosinaeng, W. B. N., \& Bria, K. (2020). Pendekatan Pendidikan Matematika Realistik Berbasis Etnomatematika Dan Prestasi Belajar Siswa. Journal of Honai Math, 3(2), 145-156. https://doi.org/10.30862/jhm.v3i2.126.

Warsito, W., \& Nuraini, Y. (2019). Desain Pembelajaran Pecahan melalui Pendekatan Realistik di Kelas V. $\begin{array}{llll}\text { Mosharafa: } \quad \text { Jurnal } & \text { Pendidikan } & \text { 25-36. }\end{array}$ https://doi.org/10.31980/mosharafa.v8i1.381.

Wati, A. R., \& Kurniasih, K. (2021). Penerapan pendekatan pmr untuk meningkatkan pemahaman konsep matematis siswa kelas i SD. Jurnal pendidikan guru sekolah dasar, 6(1). https://doi.org/https://doi.org/10.17509/jpgsd.v6i2.40027.

Yandiana, S. N., \& Ariani, Y. (2020). Pengaruh Pendekatan Pendidikan Matematika Realistik (PMR) terhadap Hasil Belajar Pecahan di Sekolah Dasar [The Effect of Realistic Mathematics Education Approach (MEA) on Learning Outcomes of Fractions in Elementary School]. Jurnal Pendidikan Tambusai, 4(3), 2945-2951.

Yanti, R., Laswadi, L., Ningsih, F., Putra, A., \& Ulandari, N. (2019). Penerapan pendekatan saintifik berbantuan geogebra dalam upaya meningkatkan pemahaman konsep matematis siswa. AKSIOMA : Jurnal Matematika Dan Pendidikan Matematika, 10(2), 180-194. https://doi.org/10.26877/aks.v10i2.4399.

Yulianty, N. (2019). Kemampuan Pemahaman Konsep Matematika Siswa Dengan Pendekatan Pembelajaran Matematika Realistik. Jurnal Pendidikan Matematika Raflesia, 4(1), 60-65. https://doi.org/10.33449/jpmr.v4i1.7530. 